\title{
Accounting
}

\section{Factors influencing tourism investment in the CLMVT countries}

\section{Chaturaporn Sihabutr ${ }^{a}$, Malliga Sompholkranga, Sukanya Sirimat ${ }^{\mathrm{a}}$, Kamolthip Panyasit ${ }^{\mathrm{a}}$ and Sakkarin Nonthapot ${ }^{\mathrm{a}^{*}}$}

${ }^{a}$ Faculty of Interdisciplinary Studies, Khon Kaen University, Nong Khai Campus, Thailand

\begin{tabular}{l}
\hline C H R O N I C L E \\
\hline Article history: \\
Received: January 1, 2021 \\
Received in revised format: \\
January 232021 \\
Accepted: February 15, 2021 \\
Available online: \\
February 15, 2021 \\
\hline Keywords: \\
CLMVT countries \\
GMS \\
Tourism investment
\end{tabular}

\section{H R O N I C L E}

\section{Introduction}

The countries in the Greater Mekong Sub-region (GMS) promote tourism under a single tourism market policy. The main members of the GMS comprise Cambodia, Laos, Myanmar, Vietnam and Thailand and are referred to as the CLMVT countries although the GMS also includes the Yunnan and Guangxi Provinces of China. Under this tourism policy, all CLMVT members invited domestic and foreign investors to invest in the tourism and service sectors.

The World Travel and Tourism Council (2020) reported that capital investment in the tourism sector in CLMV countries has gradually increased. Fig. 1 shows the volume of tourism investment in the last two decades which increased by approximately 393 Billion USD from 16 Billion USD in 2000 to more than 409 Billion USD in 2019. This demonstrates that tourism investment in the CLMV countries is a key factor that drives economic development in the region.

As a result, the CLMV countries have become one of the most favorable foreign direct investment (FDI) destinations in the world. The tourism sector has attracted investment in this region. Selvanathan et al. (2012), and Nonthapot (2017) found that foreign investors believe that FDI enhances the host country's overall development, and that tourism investment is a significant sector as well. Moreover, the tourism sector in each CLMVT country has cooperated with the tourism investment policy to enhance the tourism market potential of this area. However, the expansion of tourism investment may be affected by other factors.

\footnotetext{
* Corresponding author.

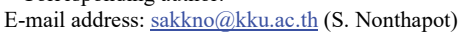

\begin{abstract}
The objective of this research is to examine the factors that affect tourism investment in the CLMV quarterly data from 2000 - 2019. Data analysis employs the panel unit root test estimated by fixed tourism investment while the number of internation tourists and Gross Domestic Product (GDP) positively affect tourism investment. Therefore, in each CLMVT country, the relevant authorities and pursue policies thable Minimum Loan Rate (MLR), target tourism promotion as a single region sector and enhance the economic system of the CLMVT countries.
\end{abstract}

(C) 2021 by the authors; licensee Growing Science, Canada 


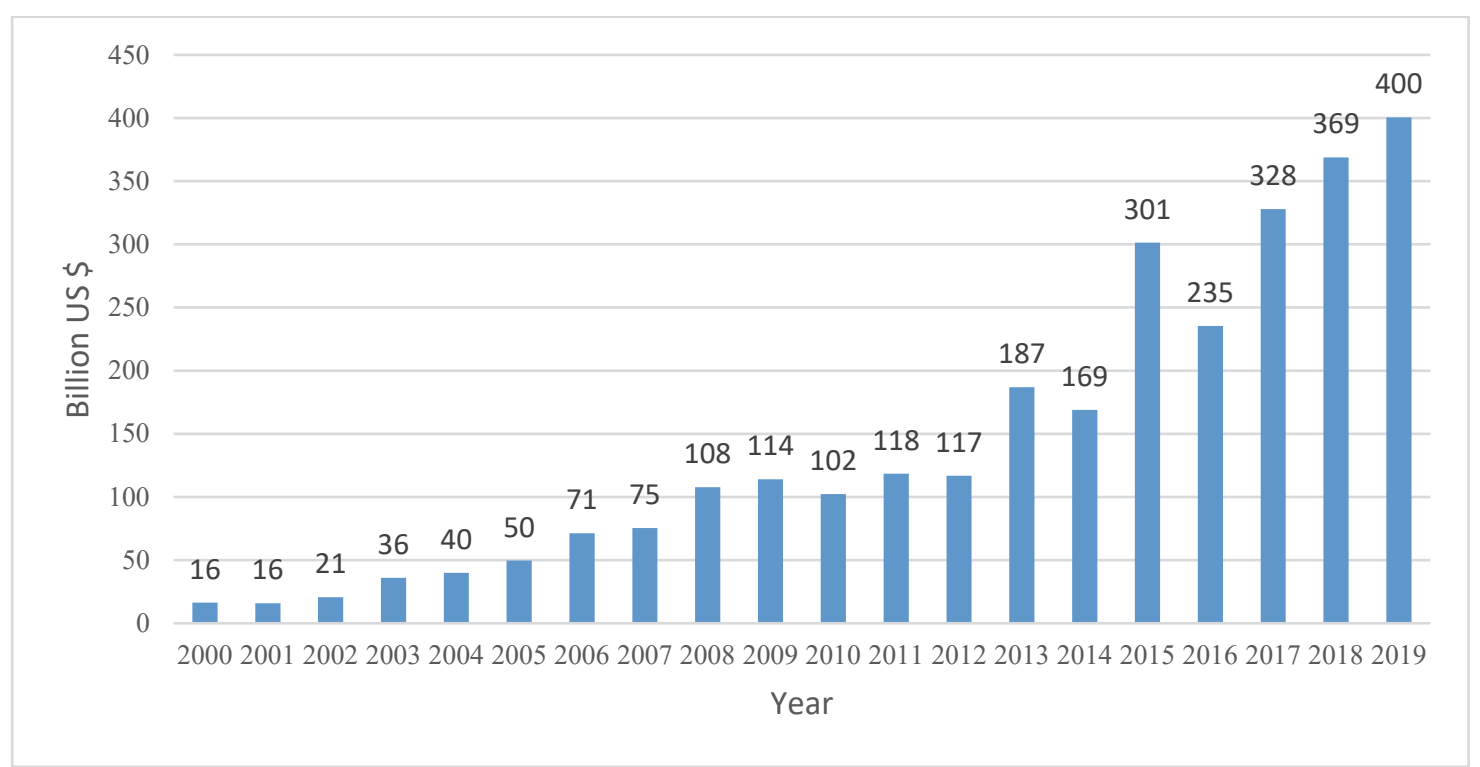

Fig. 1. Tourism Investment in the CLMV countries from 2000 - 2020

As mentioned above, tourism investment in the CLMVT countries is gradually expanding. However, the factors that affect capital investment in the tourism sector in the CLMVT countries as a whole have not been examined empirically. In order to be fill the gap in the research and to help to improve decision-making in tourism policy planning, panel data were collected and analyzed. The next section presents the literature review; section 3 describes the research methodology, section 4 presents the empirical results, and section 5 presents the conclusions.

\section{Literature Review}

Based on Keynesian investment theory, the interest rate is a factor that affects investment (Baillie \& McMahon, 1981; Wuhan, Suyuan \& Khurshid, 2015). In addition, according to classical theory, investment is also affected by income (Sax, 2006; Phutornkotara \& Nonthapot., 2020). These are the basic factors that affect short-term and long-term investment according to macroeconomic theory. In addition, Wattanakul \& Watchalaanun (2017) confirmed that the exchange rate should also be considered in regard to foreign direct investment (FDI). Many studies have investigated the factors affecting capital investment in the tourism sector. FDI has been selected as a capital investment factor in various studies such as Selvanathan et al. (2012) and Samimi et al. (2013). The results revealed that tourism had an impact on FDI in the short-run and the long-run. Geyikdagi (1995) also studied the impact of tourism on foreign investment and it was found international tourist arrivals had a relationship with gross fixed investment in Turkey. Moreover, Geyikdagi (1995) also approximated the investment factor by employing the number of accommodation establishments and the provision of new transport facilities. The results indicated that the investment factor significantly affected tourist arrivals in Turkey. Tourism has been investigated by many authors because the tourism industry is related to many sectors. Endo (2006) found that FDI in tourism was more critical and more efficient than total FDI because it was found to be strongly related to economic development in Vietnam. In addition, the number of international tourist arrivals in Economic Co-operation and Development (OECD) countries had a relationship with FDI in the real estate sector (Fereidouni \& Al-mulali, 2014).

In a study of the factors affecting tourism investment in the CLMVT countries, Sadi and Henderson (2001), found that FDI had a relationship with tourism in Vietnam. Likewise, Nonthapot (2017) conducted a study on capital investment, as opposed to foreign direct investment, in the tourism sector by analyzing the number of foreign tourists visiting ASEAN countries. It was found that investment in the tourism sector increased the number of foreign tourists visiting ASEAN in the long run. Moreover, in the CLMVT countries, the relations between major international tourist markets were also significant. This confirmed that the tourism market can attract investors in the tourism sector. In conclusion, the empirical data from previous studies focused on factors affecting FDI, FDI in the tourism sector and FDI in the real estate sector to explain capital investment in the tourism sector. However, Nonthapot (2017) confirmed that foreign direct investment in tourism is an investment alternative, which is consistent with Sadi and Henderson (2001). Therefore, this study will examine the factors affecting capital investment in the tourism sector in the CLMV countries as a whole region by employing panel data. 


\section{Research Methodology}

\subsection{Data and Data collection}

This research employs quarterly data from 1981 to 2019 which were obtained from the CLMV countries, which comprise Cambodia, Laos, Myanmar, Malaysia, Vietnam and Thailand. Tourism investment is used to represent capital investment in the tourism sector and includes capital investment spending by all sectors directly involved in the travel and tourism industry. These data were collected from the World Tourism Council research report statistics. The exchange rate (local currency per Dollar) at market prices, the Gross Domestic Product at market prices, the Minimum Loan Rate (IR) and the number of international tourists were collected from the CEIC DataBase.

\subsection{Methodology}

The factors affecting tourism investment in the CLMV countries were identified from the review of relevant concepts, theories and research. The model of the factors affecting tourism investment is presented in a natural logarithm functional form as follows:

$$
\mathrm{LnCI}_{\mathrm{it}}=\alpha+\beta_{1} \mathrm{LnEX}_{\mathrm{it}}+\beta_{2} \mathrm{LnGDP}_{\mathrm{it}}+\beta_{3} \ln \mathrm{IR}_{\mathrm{it}}+\mathrm{LnQT}+\mathrm{V}_{\mathrm{it}}
$$

where:

$\beta_{1}, \beta_{2}, \beta_{3}$ and $\beta_{4}=$ coefficient of independent variables

$\alpha=$ intercept

$C I=$ Tourism investment of country $\mathrm{i}$ at the time $\mathrm{t}$

$E X=$ Exchange Rate (local currency per Dollar) of country $i$ at the time $\mathrm{t}$

$G D P=$ Gross Domestic Product at the market price of country i at the time $\mathrm{t}$

$I R=$ Minimum Loan Rate of country $\mathrm{i}$ at the time $\mathrm{t}$

$Q T=$ Number of international tourist arrivals in country $\mathrm{i}$ at time $\mathrm{t}$

$\mathrm{i}$ = CLMVT countries: Cambodia, Laos, Myanmar, Vietnam and Thailand

$\mathrm{t}=$ quarter 1 of 2000 to quarter 4 of 2019 (80 quarters)

Eq. (1) is the macro-panel model because $\mathrm{T}=80, \mathrm{~N}=5$ (Eberhardt, 2011). The existence of individual effects is potentially correlated with the right-hand side of the regression, such that $\mathrm{V}_{\text {it }}$ is the fixed effects decomposition of the error term and the expected signs of the coefficients of explanatory variables are $\beta_{1}, \beta_{2}, \beta_{4}>0$ and $\beta_{3}<0$ and. In the next section, a panel unit root test is the first step. If all variables are mixed with $\mathrm{I}(0)$ and $\mathrm{I}(1)$ or all variables are stationary $\mathrm{I}(1)$, panel co-integration testing will be conducted.However, if all variables are stationary at I(0) we can employ the traditional panel data by conducting fixed effect or random effect estimation based on the ordinary least square procedure. The empirical model is validated by employing the Hausman test (Hausman \& Taylor, 1981).

\section{Empirical Results}

\subsection{Panel Unit Root Tests}

The results of the IPS panel unit root test of the variables from W-stat with an individual intercept indicate that the import value of tourism investment, the exchange rate, and gross domestic product are stationary at $\mathrm{I}(0)$ (see Table 1$)$. This means all variables do not need to be considered in the panel cointegration method because all variables are stationary. Hence, Pedroni (2009)'s procedure can be employed, which focuses on fixed effect or random effect estimation.

\section{Table 1}

Results of Panel Unit Root test

\begin{tabular}{ccccc}
\hline Variables & \multicolumn{2}{c}{ Im, Pesaran and Shin W-stat (Level) } & Im, Pesaran and Shin W-stat (First Difference) \\
\hline LnCI $_{\text {it }}$ & $-1.86^{* *}$ & {$[7]$} & $-5.79^{* * *}$ & {$[2]$} \\
$\operatorname{LnEX}_{\text {it }}$ & $-5.56^{* * *}$ & {$[4]$} & $-4.16^{* * *}$ & {$[3]$} \\
LnGDP $_{i t}$ & $-4.55^{* * *}$ & {$[2]$} & $-8.36^{* * *}$ & {$[2]$} \\
LnIR $_{\text {it }}$ & $-4.24^{* * *}$ & {$[1]$} & $-9.32^{* * *}$ & {$[1]$} \\
$\mathrm{LnQT}_{i t}$ & $-5.08^{* * *}$ & {$[2]$} & $-8.78^{* * *}$ & {$[2]$} \\
\hline
\end{tabular}


Note; $* *$ at the $95 \%$ confidence level $\quad * * *$ at the $99 \%$ confidence level

4.2 Estimation Results

Because all variables are stationary at $\mathrm{I}(0)$, the estimation result of the panel data model needs to consider fixed or random effects by conducting the Hausman test (Hausman \& Taylor, 1981). The results presented in Table 2 reveal that the random effect is rejected because an alternative hypothesis is accepted. This indicates that the fixed effect is appropriate.

Table 2

Cross-section random effect testing results

\begin{tabular}{|c|c|c|c|c|}
\hline Test Summary & \multicolumn{2}{|c|}{$\chi^{2}$ Statistic } & $\chi^{2}$ d.f. & Prob. \\
\hline Cross-section random & \multicolumn{2}{|c|}{725.34} & 4 & 0.00 \\
\hline \multicolumn{5}{|c|}{ Cross-section random effects test comparisons } \\
\hline Variables & Fixed & Random & Var (Diff.) & Prob. \\
\hline $\operatorname{LnEX}_{\mathrm{it}}$ & 0.05 & 0.16 & 0.002 & 0.04 \\
\hline LnGDP $_{\text {it }}$ & 0.10 & -0.20 & 0.003 & 0.00 \\
\hline $\mathrm{LnIR}_{\mathrm{it}}$ & -0.44 & 0.13 & 0.004 & 0.00 \\
\hline $\mathrm{LnQT}_{\text {it }}$ & 0.19 & 0.42 & 0.004 & 0.00 \\
\hline
\end{tabular}

Source: from calculation

The final estimation model is presented in Table 3. The fixed model estimation results show that the Minimum Loan Rate factor $\left(\ln I R_{i t}\right)$ is negatively related to factors affecting tourism investment $\left(\ln \mathrm{CI}_{\mathrm{it}}\right)$ at the one percent significance level. In addition, the number of international tourist factor positively affects tourism investment at the five percent significance level. These results meet expectations. Income, or Gross Domestic Product, $\left(\operatorname{LnGDP}_{\mathrm{it}}\right)$, is positively related to tourism investment at the ten percent significance level. However, the Exchange Rate $\left(\operatorname{lnEX}_{\mathrm{it}}\right)$ is insignificant.

Table 3

Fixed Effect Panel Estimation Results

\begin{tabular}{ll}
\hline Variables & Coefficients \\
\hline Constant & $16.20^{* *}$ \\
LnEX $_{\text {it }}$ & 0.05 \\
LnGDP $_{\text {it }}$ & $0.10^{*}$ \\
LnIR $_{i t}$ & $-0.44 * * *$ \\
$\ln \mathrm{QT}_{i t}$ & $0.18^{* *}$ \\
\hline
\end{tabular}

$\mathrm{R}^{2}=0.73$, S.E. of regression $=0.80, \mathrm{~F}=132.78 * * *$

Note: The asterisks $* * * * * *$, denote significance at the $1 \%, 5 \%$ and $10 \%$ levels of significance, respectively.

\section{Conclusion and Discussion}

This study identified the factors affecting tourism investment in Cambodia, Laos, Myanmar, Vietnam and Thailand or CLMVT countries using a panel data approach. The results reveal that interest rate (GDP) is the most significant factor and has a negative sign. This result is in accordance with investment theory by which an increasing interest rate leads to a reduction in investment in CLMVT countries of $44 \%$. This follows Keynesian theory (Wuhan et al., 2015). The next variable is the number of international tourist arrivals in CLMVT countries. This result reveals that tourism expansion can encourage capital investment in the tourism sector and also can create employment and thus economic growth. This is consistent with the findings of Nonthapot (2017). Moreover, the result is consistent with classical theory because when income increases, investment will increase as well. Consequently, the income of CLMVT countries, which is represented by GDP, can encourage capital investment in the tourism sector. However, the exchange rate is insignificant because the exchange rate for each CLMVT country depends on the origin and characteristics of tourists and the single destination policy (Nonthapot, 2016). The policy implications are as follows: 1 . The interest rate is the key factor affecting tourism investment in CLMVT countries. Therefore, the government of each CLMVT country should employ a suitable Minimum Loan Rate (MLR) as a monetary tool to expand or contract demand and to stabilize/manipulate the exchange rate/foreign exchange reserves. It also affects public borrowing/lending, bond prices and stocks. Moreover, they should implement an intensive financial policy using the MLR to encourage tourism investment 2 . The number of international tourist arrivals has a major role in driving tourism investment in 
the CLMVT countries, who should target tourism promotion as a single region to attract investment in the tourism sector in the CLMVT countries, which may lead to the expansion of the tourism sector in the region 3. Income is the key factor affecting tourism investment in the CLMVT countries. When income increases, investment is more likely to increase. Hence, the CLMVT countries should focus on measures that enhance the economy. These policies would support employment in the tourism sector and maintain growth in the economies of the CLMVT countries.

\section{References}

Baillie, R. T., \& McMahon, P. C. (1981). Interest rates and investment in West Germany. Empirical Economics, 6(1), 1-9.

Eberhardt, M. (2011). Panel time-series modeling: New tools for analyzing xt data. Retrieved from http://repec.org/usug2011/UK11_Eberhardt.pdf

Endo, K. (2006). Foreign direct investment in tourism-flows and volumes. Tourism Management, 27(4), 600-614.

Fereidouni, H. G. \& AL-mulali, U. (2014). The interaction between tourism and FDI in real estate in OECD countries. Current Issues in Tourism, 17(2), 105-113.

Geyikdagi, N. (1995) Investment in Tourism Development and the Demand for Travel. Rivista Internazionale di Scienze Economiche e Commerciali, 42, 391-403.

Hausman, J., \& Taylor, W. (1981). Panel Data and Unobservable Individual Effects. Econometrica, 49, 1377-1398.

Nonthapot, S. (2016). Mediation Between Tourism Contribution and Economic Growth in the Greater Mekong Subregion. Asia Pacific Journal of Tourism Research, 21(2), 157-171.

Nonthapot, S. (2017). Causality between capital investment in the tourism sector and tourist arrivals in ASEAN. Journal of Advanced Research in Law and Economics. 8(8), 2504-2511.

Nonthapot, S. (2020). The relationships among the five key foreign tourist markets in the Greater Mekong sub-region. Decision Science Letters. 9(4), 511-520

Pedroni, P. (1999). Critical Values for Cointegration Tests in Heterogeneous Panels with Multiple Regressors. Oxford Bulletin Economics Statistics, 61, 653-678.

Phutornkotara, K. \& Nonthapot, S. (2020). The effects of macroeconomic factors on the rate of return of securities. Accounting, $6(7), 265-1274$.

Sadi, M. A., \& Henderson, J. C. (2001). Tourism and foreign investment in Vietnam. International Journal of Hospitality \& Tourism Administration, 2(1), 67-90.

Samimi, A. J., Sadegh, S. \& Sadeghi, S. (2013). The relationship between foreign direct investment and tourism development: evidence from developing countries. Institutions and Economies, 5(2), 59-68.

Sax, C. (2006). Interest Rates and Exchange Rate Movements: Analyzing Short-term Investments in Long-term Bonds [J]. Financial Markets and Portfolio Management, 20(2), 205-220.

Selvanathan, S., Selvanathan, E. A. \& Viswanathan, B. (2012). Causality between foreign direct investment and tourism: Empirical evidence from India. Tourism Analysis, 17(1), 91-98.

The World Travel and Tourism Council. (2020). Economic Impact Research. Retrieved from http://www.wttc.org/research/economic-data-search-tool

Wattanakul, T. \& Watchalaanun, T. (2017). The relationship between foreign direct investment from Thailand and export on the economic growth of Laos. Australasian Accounting, Business and Finance Journal, 11(3), 55-66.

Wuhan, Suyuan, L. \& Khurshid, A. (2015). The effect of interest rate on investment: Empirical evidence of Jiangsu Province. China Journal of International Studies, 8(1), 81-90. 
(C) 2021 by the authors; licensee Growing Science, Canada. This is an open access article distributed under the terms and conditions of the Creative Commons Attribution (CC-BY) license (http://creativecommons.org/licenses/by/4.0/). 